\title{
IAMJ
}

INTERNATIONAL

AYURVEDIC

MEDICAL JOURNAL

\section{A COMPARATIVE CLINICAL STUDY TO EVALUATE THE EFFICACY OF KANJIKADI GHRITA AND AMRUTADI GHRITA SNEHAPANA FOR VIRECHANA IN AMAVATA WITH SPECIAL REFERENCE TO RHEUMATOID ARTHRITIS}

\author{
Kavya J H ${ }^{1}$, Rajesh Sugur², Doddabasayya ${ }^{3}$ \\ ${ }^{1} \mathrm{PG}$ Scholar, ${ }^{2}$ Guide, ${ }^{3} \mathrm{HOD}$ \\ Dept. of PG Studies in Panchakarma, TGAMC, Ballari, Karnataka, India
}

Corresponding Author: drkavyajabale@gmail.com

\section{https://doi.org/10.46607/iamj0909112021}

(Published Online: November 2021)

Open Access

(C) International Ayurvedic Medical Journal, India

Article Received: 21/10//2021 - Peer Reviewed: 13/11/2021 - Accepted for Publication: 17/11/2021

\section{Check for updates}

\begin{abstract}
Amavata is a Vata and Kapha Pradhana Vyadhi caused due to Viruddha Ahara and Vihara resulting in Mandagni, leading to the formation of Ama. Ama with the influence of Vata Dosha circulates all over the body and gets lodged in Shleshma Sthana in Sandhi Pradesha, resulting in the manifestation of Amavata. Snehapana is a mandatory Poorvakarma before Shodhana. Snehapana does the Uthklesha of Doshas before Shodhana, without which proper achievement of Shuddhi is not possible. Snehapana and Virechana are the main lines of treatment for Amavata. To evaluate the better result, here for Snehapana Kanjakadi Ghrita \& Amruthadi Ghrita were taken before Virechana which is then compared and analysed statistically. A minimum of 40 patients, fulfilling the diagnostic and inclusion criteria of Amavata according to Ayurveda classics and based on criteria fixed by the American Rheumatology Association (ARA) in 1988 criteria will be selected and randomly assigned into 2 groups, i.e. Group A and Group B consisting minimum of 20 patients in each group. Comparative analysis of the overall effect of the treatments in both groups was done statistically with the Unpaired T-Test. The test shows that the treatment is statistically not significant in Group A when compared to Group B. Overall result of Group A is $25.08 \%$ and the overall result of Group B is $31.07 \%$.
\end{abstract}


Keywords: Amavata, Kanjikadi Ghrita, Amritadi Ghrita, Snehapana, Virechana

\section{INTRODUCTION}

Ayurveda is a system of medicine which widely regarded as the oldest form of healthcare in the world; it is an intricate medical system that originated in India thousands of years ago. Most of the diseases are manifested due to improper diet and regimens. Amavata is one such disease caused due to the impairment of Agni. Amavata is a disease caused due to Ama and vitiation of Vata dosha. Due to Mandagni, there will be the formation of Ama ${ }^{l}$. Prakupita Vata takes away the Ama and gets lodged in Shleshmasthanas leading to the manifestation of symptoms such as Angamarda, Aruchi, Trishna, Alasya, Gourava, Jwara, Apaka, Angashoonata $^{2}$. In later stages, severe pain (Vrishchika Viddhavath) and swelling in Hastha, Pada, Shiras, Gulpha, Trika and Janu Sandhi, Agnimandya, Praseka, Aruchi, Gourava, Utsahahani, Vairasya, Daha, Bahumootrata, Kukshishoola, Nidraviparyaya, Trit, Chardi, Bhrama, Moorcha, Hridgraha, Vidbaddhata, Jadhya, Antrakujana and Anaha ${ }^{3}$ etc. In modern parlance, these symptoms simulate the symptoms of Rheumatoid Arthritis.

The most powerful weapon at this old age science to combat diseases is the five immensely potential therapies together called Panchakarma. Some kinds of preparatory procedures are insisted to be performed before each Shodhana therapy by Acharyas to avail the maximum benefits and to minimize the possible complications during their administration. These are termed the Purvakarma of Shodhana. The most important Purvakarma of Shodhana is Snehapana which involves the intake of suitable Sneha in a particular dose after the digestion of the previous day's meal, but without hunger. This is aimed at achieving Utklesa of vitiated Dosha lodged in Koshta, Dhatu, Srotas which is essential for their proper elimination from the body by Shodhana therapy.

Acharya Vangasena mentioned Kanjikadi Ghrita containing Hingu, Trikatu (Shunti, Pippali, Maricha) Chavya, Manimanta (Saindhava Lavana) which are processed in Kanji and Go-Ghrita in Amavata which is Deepaka and Mandagnihara ${ }^{4}$. Acharya Chakradatta mentioned Amrutadi Ghrita in Amavata which is Amashulahara and Amavatahara containing Shunti, Guduchi, Goghrita as ingridients ${ }^{5}$. Kanjikadi Ghrita and Amruthadi Ghrita is an effective and unique formulation indicated in Amavata to reverse the pathology.

Acharya Madhava has given specific etiological factors responsible for the causation of the disease Amavata as Viruddha Ahara (unwholesome diet), Viruddha Chesta (erroneous habits), Mandagni (diminished Agni), Nischalata (Sedentary life), and Exertion immediately after taking Snigdha Ahara.

Table 1: Shows different etiological factors of Amavata according to various texts

\begin{tabular}{|l|l|l|l|l|l|l|}
\hline S1. No & Nidana & Ha. S & M.N $^{7}$ & V.S & Bha.Pra $^{8}$ & G.Ni. $^{10}$ \\
\hline 1 & Viruddha Ahara & & + & + & + & + \\
\hline 2 & Guru Ahara & + & & & & \\
\hline 3 & Tarpite Kandashakaistu & + & & & & \\
\hline 4 & Mandagni & + & + & + & + & + \\
\hline 5 & Viruddha Cheshta & & + & + & + & + \\
\hline 6 & Vyavayi & + & & + & + \\
\hline 7 & SnigdhabhuktvatohiannamVyayama & & + & + & + & + \\
\hline 8 & Nischalata & & + & + & + & + \\
\hline
\end{tabular}


Table 2: Lakshanas of Amavata According to Different Acharyas:

\begin{tabular}{|c|c|c|c|c|c|c|c|}
\hline No & Symptoms & Ma. $\mathbf{N i}^{11}$ & Bh. $\mathbf{R}^{12}$ & Y. $\mathbf{R}^{13}$ & H. $\mathbf{S}^{14}$ & V.S. ${ }^{15}$ & G. Ni \\
\hline 1. & Angnisada & $\checkmark$ & $\checkmark$ & $\checkmark$ & & & $\checkmark$ \\
\hline 2. & Alasya & $\checkmark$ & $\checkmark$ & $\checkmark$ & & $\checkmark$ & $\checkmark$ \\
\hline 3. & Amatisara & & & & $\checkmark$ & & \\
\hline 4. & Anaha & $\checkmark$ & $\checkmark$ & $\checkmark$ & & $\checkmark$ & $\checkmark$ \\
\hline 5. & Anga-vaikalya & & & & $\checkmark$ & & \\
\hline 6. & Angamarda & $\checkmark$ & $\checkmark$ & $\checkmark$ & & $\checkmark$ & \\
\hline 7. & Anga shunata & $\checkmark$ & $\checkmark$ & $\checkmark$ & & $\checkmark$ & \\
\hline 8. & Apaka & $\checkmark$ & $\checkmark$ & $\checkmark$ & & $\checkmark$ & \\
\hline 9. & Aruchi & $\checkmark$ & $\checkmark$ & $\checkmark$ & & $\checkmark$ & $\checkmark$ \\
\hline 10. & Antrakuchana & $\checkmark$ & $\checkmark$ & $\checkmark$ & & $\checkmark$ & $\checkmark$ \\
\hline 11. & Asyavairasya & $\checkmark$ & $\checkmark$ & $\checkmark$ & & $\checkmark$ & \\
\hline 12. & Bahumutrata & $\checkmark$ & $\checkmark$ & $\checkmark$ & & $\checkmark$ & $\checkmark$ \\
\hline 13. & Bhrama & $\checkmark$ & $\checkmark$ & $\checkmark$ & & $\checkmark$ & $\checkmark$ \\
\hline 14. & Chardi & $\checkmark$ & $\checkmark$ & $\checkmark$ & & $\checkmark$ & \\
\hline 15. & Daha & $\checkmark$ & $\checkmark$ & $\checkmark$ & & $\checkmark$ & $\checkmark$ \\
\hline 16. & Daurabalya & $\checkmark$ & $\checkmark$ & $\checkmark$ & & & \\
\hline 17. & Gatra Stabdhata & & $\checkmark$ & $\checkmark$ & & & \\
\hline 18. & Gourava & $\checkmark$ & $\checkmark$ & $\checkmark$ & & $\checkmark$ & $\checkmark$ \\
\hline 19. & Grahani Dosha & & & $\checkmark$ & & & \\
\hline 20. & Hastapada Sandhishula & $\checkmark$ & $\checkmark$ & $\checkmark$ & $\checkmark$ & $\checkmark$ & $\checkmark$ \\
\hline 21. & Hastapada Sandhishotha & $\checkmark$ & $\checkmark$ & $\checkmark$ & $\checkmark$ & $\checkmark$ & \\
\hline 22. & Hrudaya Gourava & $\checkmark$ & $\checkmark$ & $\checkmark$ & & & \\
\hline 23. & Hrudgraha & $\checkmark$ & $\checkmark$ & $\checkmark$ & & $\checkmark$ & $\checkmark$ \\
\hline 24. & Jadyata & $\checkmark$ & $\checkmark$ & $\checkmark$ & & $\checkmark$ & $\checkmark$ \\
\hline 25. & Jwara & $\checkmark$ & $\checkmark$ & $\checkmark$ & $\checkmark$ & & $\checkmark$ \\
\hline 26. & Kandu (Kapha) & $\checkmark$ & $\checkmark$ & $\checkmark$ & & & \\
\hline 27. & Kukshikathinya & $\checkmark$ & $\checkmark$ & $\checkmark$ & & $\checkmark$ & $\checkmark$ \\
\hline 28. & Kukshishula & $\checkmark$ & $\checkmark$ & $\checkmark$ & & $\checkmark$ & $\checkmark$ \\
\hline 29. & Murchha & $\checkmark$ & $\checkmark$ & $\checkmark$ & & $\checkmark$ & $\checkmark$ \\
\hline 30. & Nidraviparyaya & $\checkmark$ & $\checkmark$ & $\checkmark$ & & $\checkmark$ & $\checkmark$ \\
\hline 31. & Praseka & $\checkmark$ & $\checkmark$ & $\checkmark$ & $\checkmark$ & $\checkmark$ & $\checkmark$ \\
\hline 32. & Sandhiroga & $\checkmark$ & $\checkmark$ & $\checkmark$ & & $\checkmark$ & \\
\hline 33. & Shirashula & $\checkmark$ & $\checkmark$ & $\checkmark$ & $\checkmark$ & $\checkmark$ & \\
\hline 34. & Staimitya (Kapha) & $\checkmark$ & $\checkmark$ & $\checkmark$ & & & \\
\hline 35. & Trikashula & $\checkmark$ & $\checkmark$ & $\checkmark$ & $\checkmark$ & $\checkmark$ & \\
\hline 36. & Trushna & $\checkmark$ & $\checkmark$ & $\checkmark$ & & $\checkmark$ & $\checkmark$ \\
\hline 37. & Utsahahani & $\checkmark$ & $\checkmark$ & $\checkmark$ & & $\checkmark$ & $\checkmark$ \\
\hline 38. & Vibandha & $\checkmark$ & $\checkmark$ & $\checkmark$ & & $\checkmark$ & $\checkmark$ \\
\hline 39. & Vairasya & $\checkmark$ & & $\checkmark$ & & & $\checkmark$ \\
\hline
\end{tabular}


Table 3: Chikitsa of Amavata according to various Acharyas.

\begin{tabular}{|c|c|c|c|c|c|c|c|}
\hline Sl. No & Upakramas(treatment) & Ch. $D^{16}$ & Bh. $\mathbf{P}^{17}$ & Y. $\mathbf{R}^{18}$ & B. $\mathbf{R}^{19}$ & V.S $\mathbf{S}^{20}$ & G. $\mathbf{N i}^{2}$ \\
\hline 1. & Langhana & + & + & + & + & + & + \\
\hline 2. & Svedana & + & + & + & + & + & + \\
\hline 3. & Tikta and Katu Dravya Prayoga & + & + & + & + & + & + \\
\hline 4. & Deepana & + & + & + & + & + & + \\
\hline 5. & Virechana & + & + & + & + & + & + \\
\hline 6. & Snehapana & + & + & + & + & + & + \\
\hline 7. & Basthi & + & + & + & + & + & + \\
\hline 8. & Valuka and Pottali Sveda & & + & + & & + & \\
\hline 9. & Sneharahita Upanaha & & + & + & & + & \\
\hline 10. & Saindhavadi Taila Anuvasana & + & & & & & \\
\hline 11. & Kshara Basthi & + & & & & & \\
\hline
\end{tabular}

\section{Materials and Methods:}

Chitrakadivati, KanjikadiGhrita, AmrutadiGhrita, Trivruth Churna, Brihat Saindhavadi Taila

Abhyanga Table, Baspha Sveda, Gas Stove, Chair, Glass, Measuring jar.

\section{Methodology}

In this clinical study, the Objective was "Comparative clinical study to evaluate the efficacy of Kanjikadi Ghrita and Amrutadi Ghrita Snehapana for Virechana in Amavata with special reference to Rheumatoid Arthritis". The efficacy was determined by finding out the difference between the baseline data of the parameters before treatment, after Snehapana, after Samsarjana and after the follow-up data.

\section{Source Of Data:}

Literary Source: Literary aspect of the study had been collected from Ayurveda classics, Modern textbooks, updated with recent medical journals and Research portals.

Sample Source: Patients with classical symptoms of Amavata fulfilling the inclusion criteria were selected randomly from OPD and IPD of Taranath Government Ayurvedic Hospital Ballari.

\section{Method Of Collection Of Data:}

Patients fulfilling the inclusive and exclusive criteria, irrespective of sex, religion, economic status were selected for the study. A special case sheet Proforma was designed with history taking, physical signs and symptoms and necessary laboratory investigations.
Study Design: A comparative clinical study. Sample Size: A minimum of 40 patients fulfilling the diagnostic and inclusion criteria of Amavata and ARA Criteria were selected and were randomly assigned into 2 groups, Group A and Group B, containing a minimum of 20 patients in each group.

\section{Diagnostic Criteria:}

- The diagnosis was based on the classical signs and symptoms of Amavata such as Sandhi Shoola, Sandhi Shotha, Sandhi Stabdhata and Aruchi.

- The 1987 revised criteria for the classification of $\mathrm{RA}^{14}$. If the patient had satisfied at least 4 of these 7 criteria. Criteria 1-4 must have been present for at least 6 weeks.

1. Morning stiffness ( $>1$ hour) six weeks or more

2. Arthritis of 3 or more joint areas six weeks or more

3. Arthritis of hand joints six weeks or more

4. Symmetric arthritis duration of six weeks or more

5. Serum rheumatoid factor

6. Radiological changes of Rheumatoid arthritis

7. Rheumatoid nodules

- CRP

- ESR

\section{Inclusion Criteria:}

- Patients presenting with classical signs and symptoms of Amavata like Sandhi Shoola, Sandhi Stabdhata, Aruchi, etc and the 1987 revised ARA criteria.

- Patients between the ages of 30-50 years irrespective of sex. 
- A patient who is fit for Snehapana and Virechana.

Exclusion criteria:

- Patients with Osteoarthritis, Psoriatic Arthritis, Sandhigatavata, Vatarakta, Rheumatic fever.
- Patients with joint deformity.

- Pregnant and lactating women.

- Patients with post-traumatic injuries.

- Patients with other systemic disorders.

Intervention: Patients were assigned into two groups consisting minimum of twenty patients in each fulfilling the inclusion criteria.

\begin{tabular}{|c|c|c|}
\hline & Group A & Group B \\
\hline $\begin{array}{l}\text { Purva } \\
\text { Karma }\end{array}$ & $\begin{array}{l}\text { Deepana - Pachana with Chitrakadi Gutika1 tid } \\
\text { before food with Ushnodaka as Anupana till Ni- } \\
\text { rama Lakshana. } \\
\text { Snehapana with Kanjikadi Ghrita is given in Aro- } \\
\text { hana Matra for 3-7 days based on Koshta and Agni } \\
\text { of the patients. } \\
3 \text { days of Vishramakala during which, Sarvanga } \\
\text { Abhyanga with Brihat Saindhavadi Taila and } \\
\text { Bhashpa Sweda with Ushnodaka was done. }\end{array}$ & $\begin{array}{l}\text { Deepana - Pachana with Chitrakadi gutikal tid before } \\
\text { food with Ushnodaka as Anupana till Nirama Lakshana. } \\
\text { Snehapana with Amritadi Ghrita is given in Arohana } \\
\text { Matra for 3-7 days based on Koshta and Agni of the pa- } \\
\text { tients. } \\
3 \text { days of Vishramakala during which, Sarvanga Ab- } \\
\text { hyanga with Brihat Saindhavadi Taila and Bhashpa } \\
\text { Sweda with Ushnodaka was done. }\end{array}$ \\
\hline $\begin{array}{l}\text { Pradhana } \\
\text { Karma }\end{array}$ & $\begin{array}{l}\text { Sarvanga Abhyanga with Brihat Saindhavadi Taila } \\
\text { and Bhashpa Sweda. } \\
\text { Virechana Karma with Trivruth lehya }\end{array}$ & $\begin{array}{l}\text { Sarvanga Abhyanga with Brihat Saindhavadi Taila and } \\
\text { Bhashpa Sweda. } \\
\text { Virechana Karma with Trivruth lehya }\end{array}$ \\
\hline
\end{tabular}

\section{Study duration and follow up}

Treatment duration: Minimum 13 days -maximum 23 days

Follow up: After 26 days for minimum and 46 days for maximum

Assessment criteria

Subjective parameters

- Sandhi Stambdhata (stiffness)
- Sandhi Shoola (joint pain)

- Aruchi (anorexia)

- Sandhi Shotha (joint swelling)

\section{Objective parameters}

- CRP

- ESR

- RA Factor

GRADINGS: The Subjective variables will be clinically assessed with the following scoring method:

Table 5: Subjective variables with gradings

\begin{tabular}{|c|c|c|}
\hline Sl.No. & Symptoms & Gradings \\
\hline 1. & $\begin{array}{l}\text { Sandhi Shoola } \\
\text { (joint pain) }\end{array}$ & $\begin{array}{l}0 \text { - No symptoms } \\
1 \text { - Alpa Shoola on forcible movements up to } 60 \text { Minutes. } \\
2 \text { - Madyama Shula on normal movements of all affected joints up to 1-4 hours. } \\
3 \text { - Teevra Shoola even on rest for more than } 4 \text { hours. }\end{array}$ \\
\hline 2. & $\begin{array}{l}\text { Sandhi Shotha } \\
\text { (joint swelling) }\end{array}$ & $\begin{array}{l}0 \text { - No symptoms } \\
1 \text { - Alpa Shotha is slightly obvious more in the affected in comparison with the normal joint. } \\
2 \text { - Madhyama Shotha covers well the bony prominences of affected joints. } \\
3 \text { - Teevra Shotha is much elevated so that joints seem grossly deformed. }\end{array}$ \\
\hline 3. & $\begin{array}{l}\text { Sandhi } \\
\text { Stabdhata }\end{array}$ & $\begin{array}{l}\text { O - No Stabdata even for } 5 \text { minutes. } \\
1 \text { - Alpa Stabdata lasts for } 5 \text { minutes to } 2 \text { hours. }\end{array}$ \\
\hline
\end{tabular}




\begin{tabular}{|c|c|c|}
\hline & (Joint stiffness) & $\begin{array}{l}2 \text { - Madhyama Stabdata for 2-8 hours. } \\
3 \text { - Teevra Stabdata more than } 8 \text { hours. }\end{array}$ \\
\hline 4. & Aruchi & $\begin{array}{l}0 \text { - No symptoms } \\
1 \text { - Alpa (rarely) } \\
2 \text { - Madyama (most of the time often) } \\
3 \text { - Teevra (always, persistent) }\end{array}$ \\
\hline
\end{tabular}

These criteria were assessed Before treatment, After Snehapana, After Samsarjana, After Follow up (taken after completion of Dviguna Parihara Kala i.e., After
26 days for minimum and 46 days for maximum). ESR, RA, CRP are assessed before treatment and after follow-up.

\section{RESULTS:}

Table 6: Comparative results of Group-A and Group-B

\begin{tabular}{|l|l|l|l|l|l|l|}
\hline Signs \& Symptoms & $\begin{array}{l}\text { Group A (Mean } \\
\text { Score) }\end{array}$ & $\begin{array}{l}\text { Group B } \\
\text { (Mean Score) }\end{array}$ & S.D $( \pm)$ & S.E $( \pm)$ & T Value & P-Value \\
\hline Sandhi Shoola & 2.01 & 2.00 & 0.503 & 0.115 & 0.10 & $>0.05$ \\
\hline Sandhi Shotha & 1.64 & 1.78 & 0.788 & 0.181 & 0.82 & $>0.05$ \\
\hline Sandhi Stambhatha & 1.86 & 1.85 & 0.641 & 0.147 & 0.09 & $>0.05$ \\
\hline Aruchi & 1.33 & 1.26 & 0.658 & 0.151 & 0.41 & $>0.05$ \\
\hline RA Factor & 24.49 & 22.92 & 9.774 & 2.242 & 0.65 & $>0.05$ \\
\hline CRP & 14.09 & 14.63 & 10.130 & 2.324 & 0.25 & $>0.05$ \\
\hline ESR & 35.50 & 35.38 & 21.368 & 4.902 & 0.03 & $>0.05$ \\
\hline
\end{tabular}

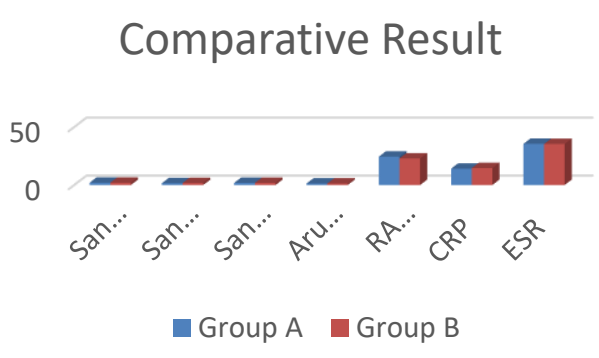

In group A, a total of 20 patients were treated out of which 1 patient got $51-75 \%$ improvement, 10 patients got 26-50\% improvement and 9 patients got 0 $25 \%$ improvement. In group B, a total of 20 patients were treated out of which 2 patients got $51-75 \%$ improvement, 12 patients got 26-50\% improvement and 6 patients got $0-25 \%$ improvement.
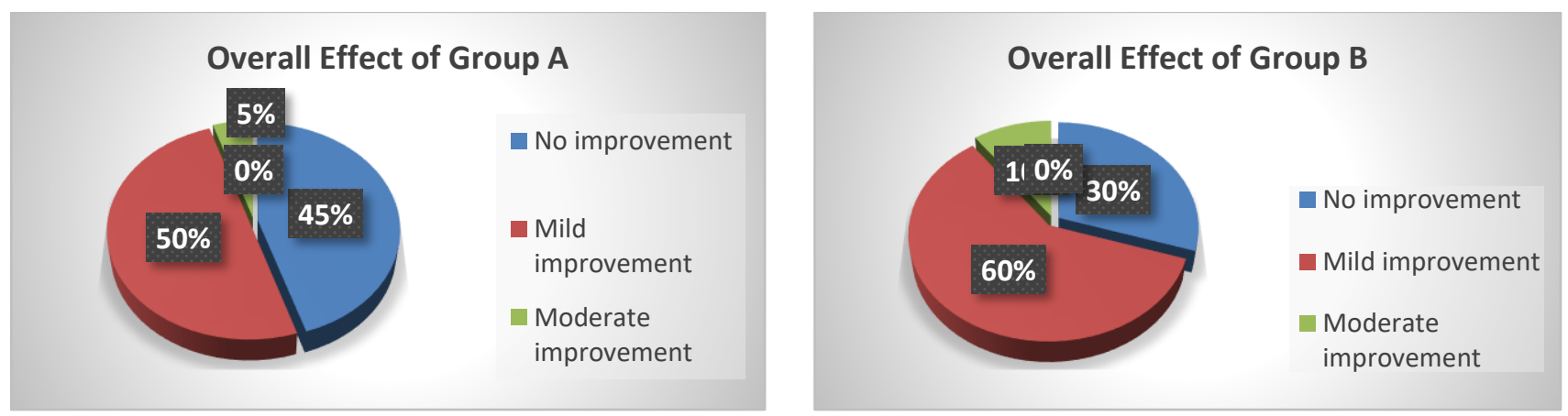


\section{DISCUSSION}

Amavata is one of the commonest disorders caused by the impairment of Agni, leading to the formation of Ama and vitiation of Vata Dosha. The Ama combines with Vata Dosha and occupies Shleshmasthana which results in Amavata Amavata can be correlated with Rheumatoid Arthritis due to similarities of clinical features. Rheumatoid Arthritis is an autoimmune disease causing chronic symmetrical polyarthritis with systemic involvement. Acharya Chakradatta mentioned Chikitsa Siddhanta for the management of Amavata, which consists of Langhana, Svedana, Tikta, Katu Rasa Prayoga, Deepana, Virechana, Snehapana and Basthi. These treatment modalities help in Amapachana, Vatashamana and Srotoshodhana and cure Amavata.

\section{MODE OF ACTION OF SNEHAPANA}

\section{1) The action of Sneha Dravya}

a. Kanjikadi Ghrita: Kanjikadi Ghrita by its name shows the importance of Kanji in it and it also contains Hingu, Shunti, Maricha, Pippali, Chavya, Goghrita and Saindhava.

By analysing Rasa-Guna-Veerya-Vipaka-Karma of the ingriedints of Kanjikadi Ghrita, it can be analysed as Kanjikadi Ghrita has Katu Rasa, Laghu, Ruksha and Teekshna Guna, Ushna Veerya, Katu Vipaka and poseses Deepana, Pachana, Shulahara, Amahara and Tridoshahara.

b. Amrutadi Ghrita: By Namarupa Vijnana, Amruta is the main ingredient of this formulation, and it also contains Shunti and Go-Ghrita.

By analysing Rasa-Guna-Veerya-Vipaka-Karma of the ingredients of Amrutadi Ghrita, it can be analysed as Amritadi Ghrita has Tiktha Rasa, Laghu, Snigdha and Teekshna Guna, Ushna Veerya, Madhura Vipaka and possesses Deepana, Shulahara, Pittahara property.

2) ACTION OF SNEHAKARMA AS A PURVAKARMA TO SHODHANA:

Sneha acts as a solvent, and it increases the Apyamsha of the body which leads to Utkleshavastha.

1) Action as a solvent: Ghee acts as a solvent for many metabolic waste products and it enters the cells easily because the cell wall is made up of phospholipids. Compared to other non-oily substances, ghee, fat materials stay in the body for a stipulated period without causing any harm and possesses better permeability property.

2) Increase in the Apyamsha of the body: This specifies the Vruddhya, Vishyandana and Kledakaraka property of Sneha. This phenomenon should be understood regarding Vruddhya i.e., increase in Apyamsha of the body which leads to Utklesha and Rasa and Kleda Vruddhi during Snehapana. After proper Snehana all the cells of the body become completely saturated with fats. Then the fat material comes out of the cell to the extracellular fluid by osmosis process. So due to the aqueous properties of Sneha and liquefied $\mathrm{Ma}$ las brought from the tissues, the level of fatty acids etc. increases in the blood resulting in the high plasma volume. To keep up the equilibrium of the normal plasma level, the extra amount of liquid from it reaches the Koshta for expulsion. This is called Anu Pravana Bhava. Later, when Virechana was administered, this increased amount of the body fluids is evacuated by which the vitiated Dosha was expelled out resulting in the radical cure of Amavata. By the combined effect of Snehana and Svedana, excessive increase of Dosha, liquefication of Dosha, digestion of Dosha, the opening of Srotomukha and control of Vata occurs so that, the Doshas come to the Koshta by Anupravana Bhava, and they are expelled out through nearest route by proper Virechana Karma.

\section{3) MODE OF ACTION OF VIRECHANA IN AMAVATA}

The administration of Virechana Karma in the patients of Amavata was effective may be due to the following reasons.

$>$ Production of Ama is a result of the involvement of both Sthanika Pitta Dosha and Kledaka Kapha. The Kledaka Kapha after leaving its normal site settles at Amasaya thus hampering the digestive activity of Pachaka Pitta. Virechana removes the Kledaka Kpaha along with Pitta. As it is also the most suited therapy for the Sthanika Dosha Pitta. 
Thus, it could have been responsible for the $A g$ nivardhana and reduced Ama production obtained in patients in this study, up to some extent.

$>$ Symptoms of Amavata like Anaha, Vibandha, Antrakujana and Kuksisula were reduced significantly after Virechana these are indicative of Pratiloma Gati of Vayu which is made Anuloma by Virechana.

$>$ Virechana is responsible for the elimination of various toxic and unwanted substances from the macro as well as microchannels of the body.

$>$ Virechana is the most suitable therapy for the Sthanika Pitta Dosha.

$>$ Chikista Sutra of Amavata consists of Langana, Svedana, Katu and Tiktha Dravya Prayoga and Deepana. All these will make the disease attain Niramavasta. Then continuing with Chikitsa Sutra Snehapana, Virechana, Basthi are mentioned. This can be analysed as after Niramavasta, one can do the utklesha of Doshas with Snehapana and can eliminate with Virechana Karma.

\section{CONCLUSION}

Snehapana is safely administered in Amavata after proper Deepana- Pachana. Shodhnanga Snehapana followed by classical Virechana is effective in Amavata. Kanjikadi Ghrita Snehapana for Virechana shows a statistically significant reduction in the symptom score of Sandhishoola, Sandhi Shotha, Sandhi Stabdhata, Aruchi and in parameters ESR, RA and CRP. Amruthadi Ghrita Snehapana for Virechana shows a statistically significant reduction in the symptom score of Sandhishoola, Sandhi Shotha, Sandhi Stabdhata, Aruchi and in parameters ESR, RA and CRP. Comparative analysis of the overall effect of the treatments in both groups was done statistically with an Unpaired T-Test. The test shows that the treatment is statistically not significant in Group A when compared to Group B. Overall result in Group A is 51.84\% and Group B is $59.14 \%$. Amruthadi Ghrita Snehapana is more effective for Virechana in Amavata than Kanjikadi Ghrita Snehapana. The treatment is effective and equally safe.

\section{REFERENCES}

1. Madhavakara, Madhava nidana with Madhukosha Sanskrith commentary, edited Prof. Yadunandana Upadhyaya, published by Choukhambha Sanskrith Samsthan, Varanasi, edition 1993, Poorvardha chap 25, verse no15, 525pp.

2. Madhavakara, Madhava nidana with Madhukosha Sanskrith commentary, edited Dr Brahmananda Tripati, published by Choukhambha Prakashana, Varanasi, edition 2009, Poorvardha chap 25, verse no6, 511pp.

3. Madhavakara, Madhava nidana with Madhukosha Sanskrith commentary, edited Dr Brahmananda Tripati, published by Choukhambha Prakashana, Varanasi, edition 2009, Poorvardha chap25, verse no7-10, 568pp.

4. Vangasena, Vangasena Samhitha Chikitsa Sara Sangraha, with Hindi commentary by Sri Shaligramaji Vaishya, edited by Sri Vaidya Shankaralalaji Jain, published by Khemaraja Shrikrushnadasa prakashana, Mumbai; edition 2003, chap55, verse no69-70, pp321.

5. Chakrapani Datta, Chakradatta with Bhavarthasandipini Hindi commentary by Sri Jagadishvaraprasad Tripati, editor Bhishagrartna Pt. Brahmashankar Mishra, Choukambha Samskrit series Varanasi edition reprint 2012, chap 25, verse no 57, 231pp.

6. Harita. Harita Samhitha, edited by kshemaraja Shreekrushnadasa, published byKhemaraja Shrikrushnadasa prakashana, Mumbai; Triteeyasthana, chap.21, verse No. 1-2, pp 361

7. Madhavakara, Madhava nidana with Madhukosha Sanskrith commentary, edited Prof. Yadunandana Upadhyaya, published by Choukhambha Sanskrith Samsthan, Varanasi, edition 1993, Poorvardha chap 25, verse no1, pp 597, pg 525.

8. Vangasena, Vangasena Samhitha Chikitsa Sara Sangraha, with Hindi commentary by Sri Shaligramaji Vaishya, edited by Sri Vaidya Shankaralalaji Jain, published by Khemaraja Shrikrushnadasa prakashana, Mumbai; edition 2003, chap53, verse 1, pg399, pp885.

9. Bhavamishra. Bhavaprakasha, edited by Hariprasad Padeykar, Varanasi: Chaukhambha Sanskrith seriesOrientalia; Madyamakhanda, $26^{\text {th }}$ chapter, verse no.1, $304 \mathrm{pp}$.

10. Sri Vaidya Shodala, Gada Nigraha, Vidyotini Hindi commentary edited by Sri Indradeva Tripati, Gangashaya Pandeya, Choukambha Sanskrith Samsthana, Varanasi 2005; Kayachilitsa Khanda, Amavatadhikara, verse no 1, pp 544 . 
11. Madhavakara, Madhava nidana with Madhukosha Sanskrith commentary, edited Prof. Yadunandana Upadhyaya, published by Choukhambha Sanskrith Samsthan, Varanasi, edition 1993, Poorvardha chap 25, verse no 12, pp 597, pg 545.

12. Bhavamishra. Bhavaprakasha, edited by Hariprasad Padeykar, Varanasi: Chaukhambha Sanskrith series Orientalia; Madyamakhanda, $26^{\text {th }}$ chapter, verse no.67, 305-307pp.

13. Anonymous. Yogaratnakara. Hindi commentary by Vaidya Lakshmipati Shastri. Edited by Bhishagratna Bhramashankar Shastri. $6^{\text {th }}$ Edition. Varanasi: Chaukambha Sanskrit Publication; 1997, Purvardha, Amavatadhikara 565pp.

14. Harita. Harita Samhitha, edited by kshemaraja Shreekrushnadasa, published byKhemaraja Shrikrushnadasa prakashana, Mumbai; Triteeyasthana, chap.21, verse No. 3-5, pp 359

15. Vangasena, Vangasena Samhitha Chikitsa Sara Sangraha, with Hindi commentary by Sri Shaligramaji Vaishya, edited by Sri Vaidya Shankaralalaji Jain, published by Khemaraja Shrikrushnadasa prakashana, Mumbai; edition 2003, chap53, verse 6-12, pg399-400, pp885.

16. Chakrapani Datta, Chakradatta with Bhavarthasandipini Hindi commentary by Sri Jagadishvaraprasad Tripati, editor Bhishagrartna Pt. Brahmashankar Mishra, Choukambha Samskrit series Varanasi edition reprint 2012, chap 25, verse no 1, pp672, pg225.

17. Bhavamishra. Bhavaprakasha, edited by Hariprasad Padeykar, Varanasi: Chaukhambha Sanskrith seriesOrientalia; Madyamakhanda, $26^{\text {th }}$ chapter, verse no14, 310pp.

18. Anonymous. Yogaratnakara. Hindi commentary by Vaidya Lakshmipati Shastri. Edited by Bhishagratna Bhramashankar Shastri. $6^{\text {th }}$ Editon. Varanasi: Chaukambha Sanskrit Publication; 1997, Purvardha, Amavatadhikara, 565pp.

19. Sri Govindadas. Bhaisajyaratnavali. Edited by Prof. Venimadhav Aswinikumar Shastri, Varanasi; Choukambha Krishnadas Academy; 2014. Amavathadhikara, verse $1,478 \mathrm{pp}$

20. Vangasena, Vangasena Samhitha Chikitsa Sara Sangraha, with Hindi commentary by Sri Shaligramaji Vaishya, edited by Sri Vaidya Shankaralalaji Jain, published by Khemaraja Shrikrushnadasa prakashana, Mumbai; edition 2003, chap53, verse 15-16, pg400, pp885.
21. Sri Vaidya Shodala, Gada Nigraha, Vidyotini Hindi commentary edited by Sri Indradeva Tripati, Gangashaya Pandeya, Choukambha Sanskrith Samsthana, Varanasi 2005; Kayachilitsa Khanda, Amavatadhikara, verse no 14, pp 548

\section{Source of Support: Nil \\ Conflict of Interest: None Declared}

How to cite this URL: Kavya J H et al: A Comparative Clinical Study To Evaluate The Efficacy Of Kan-Jikadi Ghrita And Amrutadi Ghrita Snehapana For Virechana In Amavata With Special Reference To Rheumatoid Arthritis. International Ayurvedic Medical Journal \{online\} 2021 \{cited November 2021\} Available from:

http://www.iamj.in/posts/images/upload/2698_2706.pdf 